\title{
Ketahanan Pangan Masyarakat Adat Sebagai Wujud Pemenuhan Ham Dalam Masa Pandemi Covid-19
}

\author{
Josina Augustina Yvonne Wattimena ${ }^{1}$, Vondaal Vidya Hattu ${ }^{2}$ \\ 1, 2, Fakultas Hukum Universitas Pattimura, Ambon, Indonesia \\ *E-mail: josinaaywattimena@gmail.com
}

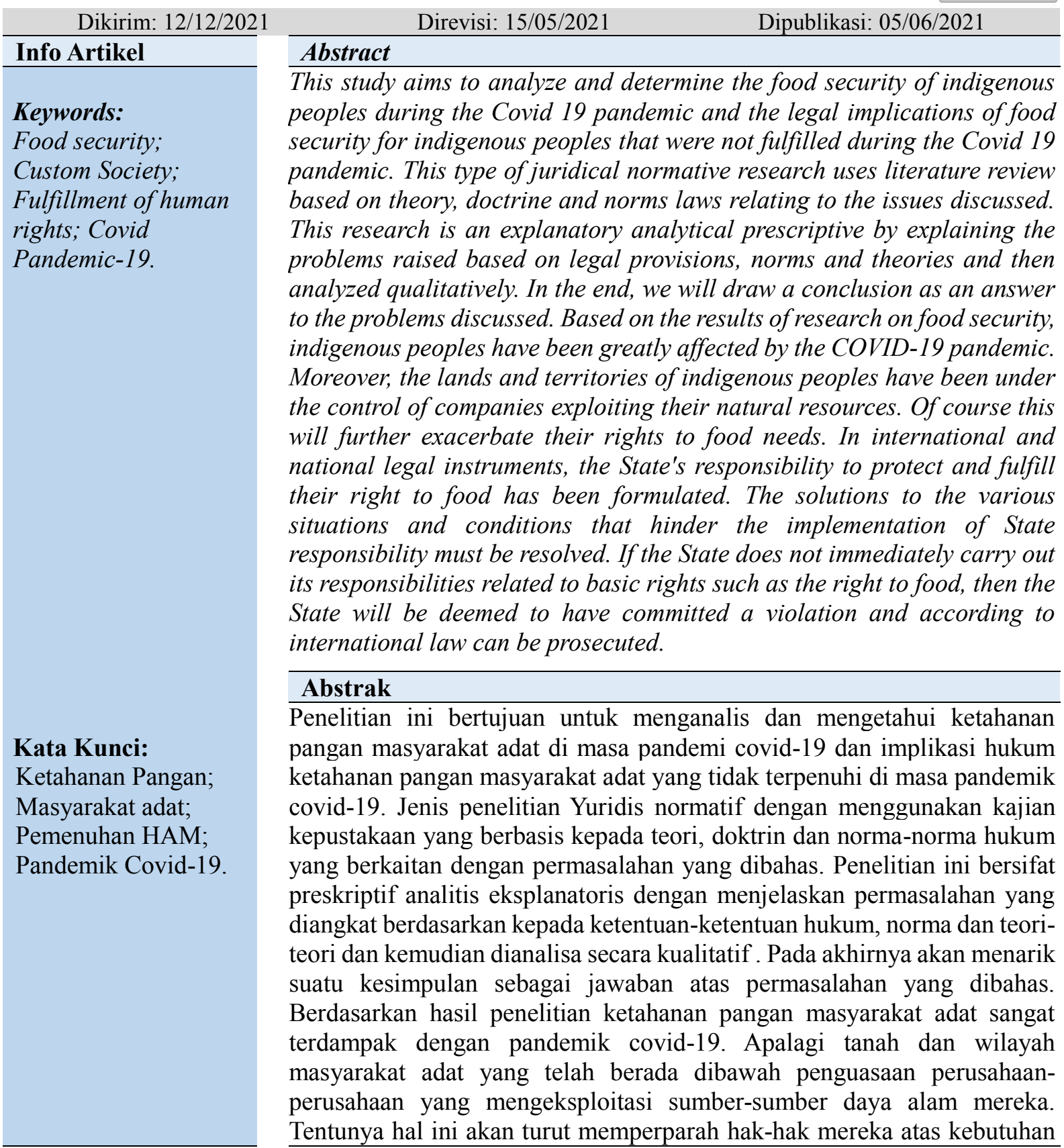


DOI:

10.47268/sasi.v27i2.448 $\overline{\text { pangan. Didalam instrument hukum internasional dan nasional telah }}$ merumuskan tanggungjawab Negara untuk melakukan perlindungan dan pemenuhan atas hak pangan mereka. Berbagai situasi dan kondisi yang merintangi pelaksanaan tanggung jawab Negara harus dapat dicarikan solusinya. Jika Negara tidak dengan segera melakukan tanggungjawabnya terkait hak-hak mendasar seperti hak atas pangan ini, maka Negara akan dianggap telah melakukan pelanggaran dan menurut hukum internasional dapat dituntut.

\section{A. PENDAHULUAN}

Hak asasi manusia (selanjutnya disebut; HAM) merupakan hak yang melekat pada esensi kehidupan manusia. HAM dimaknai sebagai anugerah Tuhan Yang Maha Kuasa diberikan pada eksistensi manusia sejak masih merupakan janin dalam kandungan. HAM dalam konsep universal tidak dibatasi oleh ruang, waktu dan dimiliki oleh semua orang. Hal ini senada dengan pendapat yang diungkapkan oleh Cranston yang dikutip dalam tulisan Yuliarso dan prajarto dengan mengatakan: "A human right by definition is a universal moral right, something which all men, everywhere, at all times ought to have, something of which no one may deprived withhout agrave affront to justice, something is owing to every human being simply because he (she] is human". . Ungkapan yang tidak jauh berbeda disampaikan oleh Chan bahwa HAM berkarakter universal untuk semua orang, waktu dan tempat dan dimiliki oleh semua manusia. ${ }^{2}$

Seiring dengan Pemahaman tentang HAM yang bersifat universal, maka serentak dengan itu pula ada kewajiban HAM untuk menghormati, dan menghargai martabat manusia dalam kesederajatan seperti yang disampaikan oleh Franz M Suseno dalam tulisannya tentang HAM, dengan "menyatakan hal prinsip dari paham HAM terletak pada kesadaran bahwa masyarakat atau umat manusia tidak dapat dijunjung tinggi kecuali bahwa setiap manusia, individu, tanpa diskriminasi, tanpa pengecualian, dihormati keutuhannya ${ }^{3}$. Rhoda E. Howard mendudukan konsep HAM dengan sangat sederhana tetapi sangat factual karena berangkat dari pengamatan terhadap keseharian dan keberlakuan HAM di segala kontekstual. Olehnya itu dia mengemukakan HAM yang dimiliki manusia karena ia adalah manusia, dan haknya ini tidak boleh diingkari, dan konsepsi ini tidak meletakan perbedaan ras, jenis kelamin, gender dan agama dan tidak lagi relevan secara politik dan hukum serta menuntut adanya perlakuan yang sama bagi semua orang. ${ }^{4}$

Konsep-konsep HAM yang diutarakan di atas hendak menjejali konsep dan pemahaman bahwa sesungguhnya HAM bersifat universal dan multidimensional sifatnya. Prinsip-prinsip HAM pada dasarnya memiliki muatan moralitas yang kena mengena dengan semua sisi kehidupan manusia. Hak-hak sipil politik memang merupakan hak yang paling awal diperjuangkan, namun demikian hak ekonomi sosial dan budaya seperti hak atas pangan, sandang dan hak atas perumahan, pendidikan, kesehatan dan lainnya merupakan hak-hak yang perlu segera dipenuhi kebutuhannya karena berkorelasi dengan kelanjutan dan kesejahteraan hidup manusia.

Di tahun 2019 dunia dikejutkan dengan penyebaran virus covid-19, yang awal mulanya berkembang di kota Wuhan China dan dengan cepat tersebar ke semua benua, Asia, Amerika, Eropa dan Afrika dan hampir dipastikan tidak ada satupun Negara yang tidak terkena dengan

1 Yuliarso, K. K., \& Prajarto, N. (2005). HAM di Indonesia: Menuju'Democratic Governances'. Jurnal Ilmu Sosial dan Ilmu Politik, 8(3), 291-308. DOI: https://doi.org/10.22146/jsp.11046.

2 Ibid.

3 Suseno, F. M. (2001). Etika Politik: Prinsip-Prinsip Moral Dasar Kenegaraan Modern, Jakarta: Gramedia Pustaka Utama, h. 145

${ }^{4}$ Howard, R. E. (2000). HAM Penjelajahan Dalih Relativisme Budaya. (Terjemahan.), Kajatasungkana, Nugraha. Jakarta: Pustaka Utama Grafitri, h. 1.

$$
\text { 248|SASI Vol. } 27 \text { No.1, Januari-Maret } 2021
$$


virus yang menular dan mematikan ini, di mana penyebaran virus ini sangat cepat dapat menyerang beberapa orang sekaligus bahkan seluruh penduduk atau masyarakat yang ada di dalamnya ${ }^{5}$. Situasi dan kondisi ini sangat mencemaskan serta menakutkan karena dampak virus ini mengena hampir semua sendi-sendi kehidupan. Kesehatan, pendidikan ekonomi, politik harus mengalami perubahan dan hukum harus segera ditetapkan dan dibentuk untuk mengatur situasi dan kondisi yang berubah dengan sangat cepat ini.

Sebagian besar negara-negara di Eropa seperti Inggris, Perancis, Italia dan diikuti Negaranegara lainnya dengan cepat menerapkan lock down dengan tujuan membatasi pergerakan masuk dan keluarnya manusia demi dan untuk memutuskan mata rantai covid-19. Penerapan ini sejalan dengan Konsep lock down yang dikutip definisinya dari Cambridge, sebagai sebuah situasi di mana orang tidak diperbolehkan masuk atau meninggalkan sebuah kawasan secara bebas karena sedang dalam kondisi darurat ${ }^{6}$. Tentunya kebijakan lock down akan berpengaruh luas bagi semua Negara-negara yang dalam era globalisasi dan pasar bebas ini sudah saling bergantung satu dengan yang lainnya. Olehnya itu ketidaktabilan pangan akan mengalami ancaman yang cukup serius.

Situasi dan kondisi yang demikian Organization Food and Agriculture (Organisasi Pangan dan Pertanian Dunia: FAO) telah mengingatkan negara-negara anggotanya, ikhwal ancaman krisis pangan global ${ }^{7}$. FAO meminta rantai pasokan makanan tetap terjaga. Organisasai dunia Perserikatan Bangsa-Bangsa mengingatkan bahwa pandemi Covid-19 mengancam pasokan pangan global karena adanya kebijakan yang dibuat oleh Negara untuk memutus mata rantai pandemic covid-19 berupa pembatasan Negara sebagaimana yang dilansir dari CNN Indonesia ${ }^{8}$.

Sebelum pandemik covid-19 melanda dunia, telah terjadi krisis pangan global selama beberap tahun dan telah membawa lebih dari seratus juta orang ke dalam kemiskinan dan menciptakan tragedy manusia. Oleh World Food Programme menggambarkan ini sebagai pelanggaran besar $\mathrm{HAM}^{9}$. Hal ini semakin diperparah dengan situasi dunia yang sementara mengalami bencana non alam covid-19. Hak atas makanan menjadi begitu sangat penting dan mendesak supaya manusia dapat meningkatkan imun tubuh berhadapan dengan virus covid-19, di sisi lain ada tantangan yang harus dihadapi ketika penerapan berbagai kebijakan untuk membatasi pergerakan keluar dan masuknya manusia dalam suatu wilayah. Perkembangan pandemik covid-19 di Indonesia berdasarkan laporan Kementerian Kesehatan RI sampai dengan bulan juli 2020 tercatat yang terpapar virus sampai dengan Juli 2020 untukuntuk keseluruhan 34 propinsi total 98.778 orang, yang sembuh berjumlah 56.655 orang serta yang meninggal berjumlah 4.781 jiwa. ${ }^{10}$. Angka-angka penderita covid-19 ini ternyata melonjak cukup drastis. Hal ini dapat dibaca melalui laman web Kementerian Kesehatan yang melaporan sampai dengan 26 Desember 2020 yang terinfeksi sebesar 700.097 penderita, yang sembuh 57.0304 orang dan meninggal 21.944 jiwa. $^{11}$

Fakta-fakta yang menggambarkan terjadinya peningkatan yang sangat tinggi akibat covid-19 ini, mengharuskan pemerintah mengambil langkah, local lock down physical

5 Sakharina, I. K. (2020). Hak Atas Pangan di Masa Pandemi Coronavirus Disease Covid-19. Jurnal Legislatif, 367-384, h. 368.

${ }^{6}$ Kennedy, P. S. J., Tampubolon, E., \& Fakhriansyah, M. (2020). Analisis Strategi Lockdown Atau Pembatasan Sosial Dalam Menghambat Penyebaran Covid-19: Sebuah Tinjauan Teoritis. Image: Jurnal Riset Manajemen, 9(1), 48-64, h. 49.

${ }^{7} \mathrm{https} / / /$ republika.co.id/berita/qg0ymn383/pandemi-covid19-ancam-ketahanan-pangan-global

${ }^{8}$ Mh Firdaus, http://asppuk.or.id/2020/06/07/pangan-lokal-di-tengah-pendemi-covid-19/

9 Zuhra, A. (2019). Ketahanan Pangan Dan Tanggung Jawab Negara Saat Konflik Bersenjata: Sebuah Tinjauan Hukum. terAs Law Review, 1(1), 98-126, h. 101.

https://infeksiemerging.kemkes.go.id/situasi-infeksi-emerging/situasi-terkini-perkembangancoronavirus-disease-covid-19-27-juli-2020.

11 https://infeksiemerging.kemkes.go.id/situasi-infeksi-emerging/situasi-terkini-perkembangancoronavirus-disease-covid-19-26-desember-2020. 
distancing dan pembatasan sosial berskala besar (PSBB). Di paruh waktu pertama antara maret samapai dengan Juli, penerapan berbagai kebijakan di atas, diikuti dengan Langkah hukum yang merupakan dasar pelaksnaan berbagai kebijakan tersebut. Ketentuan-ketentuan hukum tersebut antara lain:

1) Instruksi Presiden Nomor 4 Tahun 2020 Tentang Refocussing kegiatan, realokasi anggaran serta pengadaan barang dan jasa dalam rangka percepatan penanganan Corona Virus Disease 2019 (Covid-19).

2) Keputusan Presiden Nomor 11 Tahun 2020 Tentang Penetapan Kedaruratan Kesehatan Masyarakat Covid-19.

3) Keputusan Presiden Nomor 12 Tahun 2020 tentang penetapan bencana non alam penyebaran Corona Virus Disease 2019 (Covid-19) sebagai Bencana Nasional.

4) Peraturan Pemerintah No. 21 tahun 2020 tentang Pembatasan Sosial Berskala Besar dalam rangka Percepatan Penanganan Corona Virus Disease (Covid-19) ditetapkan di Jakarta pada tanggal 31 Maret 2020 oleh Presiden Joko Widodo.

5) Keputusan Presiden Nomor 7 Tahun 2020 Tentang Gugus Tugas Pencepatan Penanganan Corona Virus Disease 2019.

6) Keputusan Presiden Nomor 9 Tahun 2020 tentang Perubahan Atas Keputusan Presiden Nomor 7 Tahun 2020 Tentang Gugus Tugas Percepatan Penanganan Corona Virus Disease 2019 (Covid-19).

Berdasarkan UU No. 6 tahun 2018 dan Permenkes No. 9 tahun 2020, bentuk pembatasan dalam memberlakukan Pembatasan Sosial Berskala Besar (PSBB) yakni: a) peliburan sekolah dan tempat kerja; b) pembatasan kegiatan keagamaan; c) pembatasan kegiatan di tempat atau fasilitas umum; e) pembatasan moda transportasi; dan f) pembatasan kegiatan lainnya khusus terkait aspek pertahanan dan keamanan, disertai ancaman sanksi bagi yang melanggar. ${ }^{12}$

Secara keseluruhan kebijakan-kebijakan yang ditempuh oleh pemerintah ini akan berdampak sangat besar terhadap kebutuhan hidup masyarakat. Salah satu di antaranya masyarakat adat, yang dari berbagai penelusuran sumber dan referensi diperoleh gambaran bahwa ketahanan pangan masyarakat hokum adat yang ada di Indonesia berada pada tiga kriteria. Kriteria pertama komunitas yang berkelimpahan sumber pangan. Kriteria ini umumnya dimiliki oleh komunitas adat yang mempunyai kedaulatan lahan, tanah adat dan hutan. Kriteria kedua cukup sumber pangan bila lahan yang dimiliki dimanfaatkan secara maksimal.

Ketiga adalah kelompok paling rentan pangan. Kelompok ini tidak memiliki lahan, tidak memiliki akses terhadap tanah. Umumnya kelompok masyarakat adat ini adalah komunitas adat yang di wilayah adatnya hadir perusahaan, termasuk perusahaan skala besar yang banyak memakai lahan dan tanah milik masyarakat adat ${ }^{13}$. Membahas pangan dan HAM merupakan dua variable yang berelevansi sangat kuat dan mendasar. Untuk mempertahankan hidup, orang butuh pangan, sandang dan papan. Bahkan ketersediaan pangan memiliki relasi positif dengan kesejahteraan manusia. Ketahanan pangan adalah kebutuhan urgen dalam meningkatkan kesejahteraan dan kemakmuran bangsa ${ }^{14}$.

Hak atas pangan sebagai hak yang mendasar dan paling utama, tidak dapat diabaikan. Sama halnya dengan hak hidup, hak atas pangan merupakan hak yang tidak dapat dialihkan dalam kondisi apa pun (non derogable rihts). Pengabaian terhadap hak atas pangan tentunya akan mengarah kepada gizi buruk, kelaparan, kemelaratan dan daya tahan tubuh yang tidak mampu untuk menolak berbagai serangan penyakit. Pada akhirnya akan terarah kepada rapuhya

12 Sakharina, I. K. (2020), h. 370.

13 http://www.aman.or.id/2020/05/aman-perkebunan-skala-besar-perparah-krisis-pangan-di-tengah-covid$19 /$

14 El-Muhtaj, M. (2013). Dimensi-Dimensi HAM: Mengurai Hak Ekonomi, Sosial, dan Budaya. Jakarta: Rajawali Press, h. 115.

$$
\text { 250|S A S I Vo1. } 27 \text { No.1, Januari- Maret } 2021
$$


ketahanan bangsa dan Negara. Persoalan ketahanan pangan di masa pandemik ini turut diperparah dengan berbagai kebijakan yang cenderung turut menciptakan situasi dan kondisi yang tidak menguntungkan bagi kaum rentan masyarakat hukum adat, yang tanah, dan wilayahnya dikuasai oleh perusahaan-perusahaan bersklala besar.

Pooja Ahluwalia seorang pakar dan praktisi hokum yang memfokuskan diri pada pembelaan hak-hak pangan di Asia dan Africn Legal Consultative Organization (AALCO) New Delhi, India dengan pernyataannya sebagai berikut; "how ever the problems of hunger, malnutrition and starvation deaths are rampan ini various part of the world.althouh it is not confined to a few countries, howefer, in general terms, the largest food related problems are found in the developing countries, namely the countries of latin_america, Africa and Asia. What Characterized these continents is not only the shortage of food and lack infrastructure but primarily maldistribution and inadequate access to food ". ${ }^{15}$ (bagaimana masalah kelaparan, malnutrisi, dan kematian akibat kelaparan semakin merajalela di berbagai belahan dunia. Namun, kesehatan itu tidak terbatas pada beberapa negara, tetapi secara umum, masalah terkait makanan terbesar ditemukan di negara-negara berkembang, yaitu negara-negara Amerika latin, Afrika dan Asia. Apa yang dicirikan oleh benua-benua ini bukan hanya kekurangan makanan dan kurangnya infrastruktur, tetapi terutama kekurangan distribusi dan akses yang tidak memadai

Semua memaklumi bahwa masyarakat hukum adat mendiami wilayah yang jauh dan terpencil dari jangkauan dan kemudahan mengakses kebutuhan-kebutuhan hidupnya. Jika hak atas pangan masyarakat hukum adat selama ini sudah mengalami permasalahan akibat pengaambilalihan tanah, wilayah, dan sumber daya alam oleh Negara dan para pemodal ditambah dengan adanya pandemic covid-19 dengan kebijakan pembatasan sosial (PSBB) yang berakibat terbatasnya sarana distrubusi, dapat dipastikan keberlanjutan masyarakat hukum adat mengalami banyak sekali ancaman di masa pandemic covid-19.

\section{B. METODE PENELITIAN}

Metode penelitian yang dilakukan dalam penelitian ini adalah penelitian empiris dengan menghimpun data dari berbagai pihak yang memiliki komptensi. Akan tetapi tetap menggunakan kajian kepustakaan yang berbasis kepada teori, doktrin dan norma-norma hukum yang berkaitan dengan permasalahan yang dibahas. Data primer didapatkan dari masyarakat, pemerintah kabupaten, tokoh-tokoh masyarakat adat, tokoh agama, dan intitusi terkait lainnya. Data tersebut dapat diperoleh dengan wawancara dengan pihak terkait yang memiliki kompetensi untuk masalah tersebut. Penelitian ini bersifat preskriptif analitis eksplanatoris ${ }^{16}$, dengan berpijak pada data yang terkumpul, dipilah-pilah berdasarkan keterkaitannya kemudia dianalisis dengan melakukan penguraian secara kualitatif.

\section{PEMBAHASAN}

\section{Ketahanan Pangan Masyarakat Hukum Adat Sebagai Wujud Pemenuhan HAM di Masa Pandemi Covid-19}

Hak atas pangan, sandang dan perumahan akan berkorelasi positif dengan hak asasi manusia (selanjutnya disebut HAM). HAM atas pangan yang termasuk hak-hak mendasar pada awalnya diatur didalam seperangkat instrument hukum internasional yang disebut dengan International Bill of Human Rights yang termuat di dalamnya; Declaration Universal Decalaration Of Human Right, (DUHAM), International Covenant on Civil and Political Rights (ICCPR), International covenant on Economic, Social, and Cultural Rights (ICESCR),

15 Ibid. h. 116.

16 Soekanto, S. (2006). Pengantar Penelitian Hukum. Jakarta: UI-Press, h. 50. 
dan Optional Protocol to the International Covenant on Civil and Political Rights $1966^{17}$. Instrumen-instrumen hukum HAM yang diperjuangkan untuk menegakan penghormatan, perlindungan, dan pemenuhan terhadap harkat dan martabat manusia, bukanlah semata-mata digali dari system nilai dan norma-Barat melainkan memiliki dasar pijakan yang kokoh dari seluruh budaya dan agama ${ }^{18}$. Olehnya itu Eko Riyadi memberi penekanan bahwa HAM merupakan kristalisasi berbagai system nilai dan filsafat dan seluruh aspek kehidupannya ${ }^{19}$. Hal ini didasarkan pada pandangan dunia tentang HAM yang adalah kesemestaan bagi eksistensi dan proteksi kehidupan dan kemartabatan manusia ${ }^{20}$, dapat dikatakan bahwa pandangan dan konsepsi universal HAM ini meletakan dasar-dasar moral HAM yang tak disekat oleh ruang, waktu, tempat, dan dimiliki oleh semua orang.

Bercermin dan belajar dari perjalanan sejarah HAM umat manusia yang realitasnya memperjuangkan hak-hak invidu, akan tetapi dalam perkembangan, hak-hak kolektif mendapatkan pengakuan dan perlindungan melalui berbagai instrument-instrumen hukum internasional. Perlindungan masyarakat adat dapat dilihat melalui berbagai kerangka normatif dan standar internasional yang mengatur hak-hak masyarakat adat ${ }^{21}$, dengan mengelaborasi beberapa penelitian, salah satunya penelitian Ahmad Syofan, maka dapat dikemukakan beberapa instrument hukum internasional yang mengatur tentang hak-hak masyarakat Adat, seperti pangan, sandang, tempat berdiam, budaya, identitas dan lain-lain. Di antaranyanya dapat dicatat disini;

a) Deklarasi Universal Hak Asasi Manusia 1948 (Universal Declaration of Human Rights/UDHR) 1948.

b) Kovensi Internasional Hak-Hak Ekonomi, Sosial Dan Budaya 1966 (International Covenant on Economic, Social and Cultural Rights 1966).

c) Kovensi Internasional Hak-Hak Sipil dan Politik 1966 (International Covenant on Civil and Political Rights 1966).

d) Konvensi Internasional Penghapusan Segala Bentuk Diskriminasi Rasial 1965 (International Convention on the Elimination of All Forms of Racial Discrimination 1965).

e) Konvensi Tentang Keanekaragaman Hayati 1992 (Convention On Biological Diversity 1992).

f) Konvensi ILO No. 107 Tahun 1957 tentang Perlindungan dan Integrasi dari Penduduk Pribumi, Masyarakat Adat dan Masyarakat Semi-adat di Negara-negara Merdeka (Convention No.107 concerning Protection and Integration of Indigenous and other Tribal and Semi-Tribal Population in Independent Countries).

g) Konvensi ILO Nomor 169 Tahun 1989 mengenai indigenous Peoples. ${ }^{22}$

h) Konvensi mengenai Penghapusan Segala Bentuk Diskriminasi terhadap Wanita (Convention on the Elimination of All Forms of Discrimination against Women (CEDAW), 1979

i) Konvensi tentang Hak-Hak Anak (Convention on the Rights of the child) (CRC) 1989,

j) Rome Declaration on World Food Security, 1996

k) Declaration on The Right of Indegenous Peoples, 2007

Sumber-sumber hukum internasional tersebut sebagaimana di atas, sebagai dasar

17 Sanny, H., Pieris, J., \& Foekh, D. Y. P. (2021). Hak Asasi Manusia, Demokrasi dan Pancasila. to-ra, 7(Special Issue), 142-156, h. 151.

18 El-Muhtaj, M. (2013). Op. Cit, h. 11

19 Riyadi, E. (2019). Hukum Hak Asasi Manusia Perspektif Internasional, Regional dan Nasional, Depok: Rajawali Pers, h. 1.

20 El-Muhtaj, M. (2013). Op. Cit, h. 1.

21 Syofyan, A. (2012). Perlindungan Hak-Hak Masyarakat Adat Menurut Hukum Internasional. Fiat Justisia: Jurnal Ilmu Hukum, 6(2). https://doi.org/10.25041/fiatjustisia.v6no2.326, h. 3-4.

22 Ibid.

252|S A S Vol. $27 \mathrm{No.1,}$ Januari-Maret 2021 
pengakuan dan perlindungan HAM masyarakat hukum adat. Titik berangkat kerangka normatif HAM masyarakat hukum adat ini sejatinya karena mereka juga manusia yang memiliki harkat dan martabat sama seperti manusia yang lain, yang karena itu mereka juga memiliki HAM seperti yang dikatakan oleh Jack Donelly; HAM adalah hak-hak yang dimiliki manusia sematamata karena ia manusia ${ }^{23}$. HAM masyarakat hukum adat sebagai individu tidak jauh berbeda dengan individu lainnya, membutuhkan hak untuk hidup, hak atas pangan, hak atas sandang dan hak atas tempat tinggal, pendidikan, dan hak-hak lainnya. Namun demikian secara kolektif atau komunitas ada hak-hak lainnya yang membedakannya baik dari aspek pengakuan, perlindungan, pemajuan, dan pemenuhannya. Adalah wilayah, tanah, air, identitas budaya, hubungan spriritualitas mereka dengan kesemestaan dan lingkungan mereka berdiam seharusnya mengajarkan setiap pihak untuk menghormati dan menghargai mereka dalam perbedaan tanpa kekecualian, karena itulah esensi keutuhan mereka. (cetak miring oleh penulis)

Selain perjanjian internasional, dan deklarasi terdapat pula prinsip-prinsip HAM yang sudah diakui memiliki derajat sebagai jus cogens. Prinsip prinsip HAM ini sangat terkait dengan prinsip-prinsip umum hukum internasional (general principles of law) yang juga merupakan salah satu sumber hukum utama (primer) ${ }^{24}$ dengan mengutip pendapat berbagai ahli yang dirangkum oleh Edy Riyadi dalam bukunya, dikatakan bahwa pelaksanaan HAM selalu terkait erat dengan prinsip-prinsip HAM. Misalnya Manfred Nowak menyebut ada empat prinsip HAM yakni universal (universality), tak terbagi (indivisibility), saling bergantung (interdependent), saling terkait (interrelated) ${ }^{25}$. Sementara Rhona R.K. Smith menambahkan prinsip lain yaitu kesetaraan (equality) dan non diskriminasi (Non-discrimination) ${ }^{26}$. Prinsip lain yang juga penting adalah martabat manusia (human dignity) ${ }^{27}$. Oleh Edy Riyadi, Indonesia menambahkan satu prinsip lagi yaitu tanggung jawab Negara (state responsibility) sebagai kelengkapan pelaksnaan prinsip-prinsip HAM tersebut. Kesemua pengaturan mengenai HAM tersebut mengindikasikan pengakuan, dan perlindungan HAM terhadap masyarakat adat tidak diragukan lagi. Pertanyaannya kemudian secara implementatif sejalan tidak dengan regulasiregulasi yang telah ditetapkan, ini soalnya seperti beberapa kasus yang dikemukakan di bawah ini.

Kasus yang menimpa masyarakat hukum adat yang terjadi di berbagai belahan dunia bahkan di Indonesia, kekuatan hukum yang telah melegitimasi hak-hak mereka seolah tak berdaya, lemah, berhadapan dengan penguasa, kapitalis dan kepentingan-kepentingan Negara kuat dan maju. Sebagai contoh; perusahaan kayu baik dari Eropa, Afrika dan Asia, memperluas penebangan kayu pada hutan di Afrika, yang berdampak tergusurnya suku Baka dan Bakola dari wilayah adat mereka. Kasus lain di di Uni Soviet terjadi eksplorasi dan eksploitasi gas dan minyak yang meningkat di Siberia bagian Barat yang menyebabkan hilangnya tanah, 11 juta hektare padang rumput habitat rusa kutub, 20 ribu hektare lahan pengembangbiakan ikan dan lebih dari 100 sungai. Hal ini telah mengarah pada penghancuran mata pencahariaan, pengangguran, kemiskinan dan marginalisasi sosial masyarakat adat Nentz, Khanty atau Manty yang sudah secara terun temurun menempati wilayah tersebut. Eksploitasi hutan di timur laut Kamboja menghancurkan dasar penghidupan masyarakat adat perbukitan di daerah tersebut, menghancurkan pohon dan tempat tinggal mereka, serta upacara dan keyakinan yang terkait dengan kedua hal tersebut. Akibatnya menyebabkan ketidakseimbangan antara masyarakat dan hutan. Di Indonesia, kasus Tlogo, Kasus Mesuji, Kasus Sritanjung, Kesemuanya di Lampung. Kasus Sungai sodong di Sumatera Selatan, Kasus PT Sumber Mineral Nusantara di NTB ${ }^{28}$, dan masih banyak kasus lainnya yang merupakan peta konflik baik yang bersifat vertical maupun

23 Andrey, S. (2016), Hukum HAM dan Hukum Humaniter, Jakarta: Rajagrafindo Persada, h. 2.

24 Ibid.

25 Nowak, M. (2003). Introduction to The International Human Rights Regime. Brill Nijhoff, h. 27.

26 Ibid.

27 Riyadi, E. (2019). Op. Cit

28 Nugroho, O. C., \& Kav, J. H. R. S. (2018). Konflik Agraria Di Maluku Ditinjau Dari Perspektif Hak Asasi Manusia. Jurnal HAM, 9(1), 87-101, h. 84.

$$
\text { 253|SASI Vo1. } 27 \text { No.1, Januari-Maret } 2021
$$


horizontal, yang berakibat hilangnnya hak-hak mereka sebagai masyarakat hukum adat, terhadap tanah, air dan wilayah.

Menyimak berbagai fakta-fakta serta kasus yang dialami oleh masyarakat hukum adat terutama untuk menikmati HAM layaknya manusia yang lain, dapat ditarik benang merah bahwa penikmatan, perlindungan, pemenuhan hak-hak mereka, masih sebatas pengakuan di atas kertas, berbanding terbalik dengan cita-cita HAM yang didasarkan kepada prinsip-prinsip, dan konsesnsus-konsensus yang telah dibuat, oleh manusia yang bermarmartabat namun good faith dan moral setiap pihak belum siap untuk mengakui mereka masyarakat hukum adat dalam kesederajatan dan martabat beserta hak-hak yang melekat di dalamnya.

Ketahanan pangan sangat berbanding lurus dengan kesejahteraan, dan kemakmuran dari suatu bangsa. Ketahanan pangan berbicara tentang ketersediaan pangan baik melalui kegiatan swasembanda swadaya ataupun kebijakan kegiatan impor pangan, dengan mengutip batasan ketahanan pangan di dalam Deklarasi Roma 1996 ditegaskan bahwa Ketahanan pangan terjadi apabila semua orang secara terus menerus, baik secara fisik, sosial, dan ekonomi mempunyai akses untuk pangan yang memadai/cukup, bergizi dan aman, yang memenuhi kebutuhan pangan mereka dan pilihan makanan untuk hidup secara aktif dan sehat". ${ }^{29}$

Jauh sebelum rumusan ketahanan pangan ini dikonsepkan di dalam Deklarasi Roma 1996, DUHAM sebagai sebuah instrument yang memuat pernyataan moral tentang HAM masyarakat sedunia telah mendudukan konsep hak atas pangan dalam Pasal 23 ayat (1) DUHAM dengan menyebutkan "setiap orang berhak atas tingkat hidup yang memadai untuk kesehatan dan kesejahteraan dirinya dan keluarganya, termasuk hak atas pangan, pakaian, perumahan, dan perawatan kesehatan serta pelayanan sosial yang diperlukan, dan berhak atas jaminan pada saat menganggur, menderita sakit, cacat, menjadi janda atau duda, mencapai usia lanjut atau keadaan lainnya yang mengakibatkan kekurangan nafkah yang berada diluar kekuasaannya.

Konsep tersebut tergambar jelas ketahanan pangan sebagai hak dasar dari hak asasi manusia termasuk jaminan sosial lainnya merupakan hak setiap orang, dan dia berhak memperolehnya dalam situasi dan kondisi apapun. Hal ini dapat dimaklumi karena ketahanan pangan akan berkait erat dengan hak hidup dan kebelanjutan hidup, dan lebih dari itu untuk meningkatkan mutu atau kualitas hidup yang menggambarkan tingkat kesejahteraan yang tercapai. Konsep hak atas pangan yang diusung di dalam DUHAM ini sesungguhnya mengakomodir prinsip-prinsip HAM seperti universal, tidak disikriminasi, kesetaraan dan martabat manusia, dan untuk pemenuhannya membutuhkan Negara sebagai organisasi kekuasaan yang melindungi rakyatnya. Masyarakat adat dan hak atas pangan ada dalam cakupan dimaksud. Disini tampil kewajiban Negara dalam pemenuhan hak-hak tersebut.

Catatan penting berikutnya tentang Hak atas pangan yang layak, juga diatur dalam DUHAM, Pasal 25 ayat (1) bahwa: "Everyone has the right to a standard of living adequate for health and well being of himself and of his family, including food, clothing, housing and medical care and necessary social services, and the right to security in the event of unemployment, sickness, disability, widowhood, old age or other lack of livelihood in circumstances beyond his control. (Terjemahannya Deklarasi Universal Hak Asasi Manusia), Pasal 25 ayat (1) bahwa: "Setiap orang berhak atas taraf hidup yang layak untuk kesehatan dan kesejahteraan dirinya dan keluarganya, termasuk pangan, sandang, papan dan perawatan medis serta kebutuhan sosial layanan, dan hak atas keamanan jika terjadi pengangguran, sakit, cacat, janda, usia tua atau kurangnya mata pencaharian dalam keadaan di luar kendalinya. ${ }^{30}$ Sekali lagi dengan konsep yang demikian, menjadi hak setiap orang, tanpa sekat ruang, waktu dan tempat sebagai konsekwensi moralitas HAM untuk semua orang.

29 Mulyasari, G. (2016). Kajian Ketahanan Pangan dan Kerawanan Pangan di Provinsi Bengkulu. Jurnal AGRISEP Kajian Masalah Sosial Ekonomi Pertanian dan Agribisnis, 15(1), 83-90, h. 376-377.

30 Sakharina, I. K. (2020). Op. Cit

$$
\text { 254|SASI Vo1. } 27 \text { No.1, Januari-Maret } 2021
$$


Instrument hukum internasional berikutnya yakni The International Covenant on Economi, Social, and Cultural (disingkat ICESCR). Instrumen ini ditetapkan melalui resolusi Majelis Umum PBB No 2200 A (XXI) 16 Desember 1966. Instrument ini mengatur hak-hak antara lain pendidikan, kesehatan, perumahan, air, pangan, pekerjaan, jaminan sosial, kesetaraan hidup dan lingkungan yang sehat ${ }^{31}$. Hak tersebut dalam perkembangannya dikonsepkan oleh masyarakat international sebagai human security dengan dua komponen utama yaitu freedom from fear dan freedom from want ${ }^{32}$. Terkait dengan pemikiran tersebut Loetan mengatakan; "human security memberi perhatian pada individu dalam tataran praktis sangat terkait dengan pembangunan kualitas sumber daya manusia. Pembangunan dalam bidang peningkatan sumber daya manusia melalui penciptaan lapangan kerja, peningkatan pendapatan, sarana pendidikan dasar, dan lingkungan secara langsung ataupun tidak langsung sangat menentukan seberapa besar kita dapat menjamin manusia terbebas dari ketakutan dan kebutuhan dasarnya". ${ }^{33}$ Kerangka konsep berpikir yang disampaikan terkait dengan hak-hak dasar dari manusia di antaranya hak atas pangan yang harus dinikmati oleh setiap orang tanpa menengok "siapa dia" sesungguhnya hendak meletakan harkat dan martabat manusia yang bebas dari kemelaratan, kekurangan. Pembatasan-pembatasan tersebut hanya dapat dijawab oleh masyarakat internasional berdasarkan instrument-instrumen hukum baik pada level internasional dan implementasinya ada pada Negara.

Instrument ICESCR termasuk banyak meletakan hak-hak dasar dari setiap individu maupun kolektif inheren di dalamnya hak masyarakat adat. ICESR banyak mengintrodusir hakhak dasar HAM. Mulanya HAM yang diatur di dalam ICESCR sering dimaknai sebagai the second class", ketimbang hak-hak sipil politik sebagai "the first class". Image ini terbentuk kemungkinan dipengaruhi oleh pembagian HAM oleh Karel Vasak ahli hukum Perancis yang diilhami oleh Revolusi Perancis, yang membagi tiga generasi HAM: (a) generasi pertama yaitu hak-hak sipil dan politik (liberte); (b) generasi kedua yaitu hak-hak ekonomi, sosial, dan budaya (egalite); dan (c) generasi ketiga yaitu hak-hak solidaritas (fraternite) $)^{34}$. Apa yang dilakukan oleh Vasak ini hanya sebagai penanda dari perkembangan historis HAM yang pada zamannya sangat dipengaruhi oleh pergerakan untuk memenuhi kebutuhan hak-hak asasi manusia. Perjuangannya adalah untuk mengembalikan hak-hak individu yang dibelenggu oleh penguasa, bangsawan ataupun kapitalis.

Olehnya itu setiap Negara yang hendak melakukan ratifikasi akan bertindak untuk melakukan ratifikasi terhadap kedua instrument hukum ICCPR maupun ICESCR sekaligus. Sekalipun mungkin ada Negara-negara tertentu yang hanya meratifikasi salah satu dari instrument tersebut.; seperti misalnya Amerika Hanya meratifikasi ICCPR dan China ICESCR $^{35}$ Memang ada sebagian kalangan dalam melihat kedua instrument ini tidak dalam ketrekaitan dan kesalingketergantungan.

Hal ini dipengaruhi oleh kata-kata yang dipilih untuk menjelaskan kewajiban Negara dalam istilah pelaksanaan domestic menurut Pasal 2 (1) ICESCR "jauh lebih lemah dibandingkan ICCPR", pada kenyatannya kata-kata tersebut ditafsirkan hanya merujuk pada kewajiban untuk bertindak, tidak pada atas hasil dan negara-negara hanya diwajibkan untuk mencapai pelaksanaan mengenai hak-hak ekonomi sosial dan budaya secara progresif. Beberapa komentar politis bahkan tetap berpegangan bahwa hak asasi generasi kedua (ICESCR)

31 Ashri, M. (2008). Gugatan Warga dan Tanggung Jawab Nagara Dalam Pemenuhan Hak atas Pendidikan. Indonesian Journal of International Law, 5(2), 295-318.

32 Ibid.

33 Loetan, S. (2003). Millennium Development Goal (MDG) dan Program Pembangunan Nasional di Indonesia. Jurnal Hukum Internasional, 1(1), 60-77, h. 61.

${ }^{34}$ Tarigan, J. P. (2017). Akomodasi Politik Hukum di Indonesia terhadap Hak Asasi Manusia Berdasarkan Generasi Pemikirannya. Jurnal Konstitusi, 14(1), 168-187. DOI: https://doi.org/10.31078/jk1418, h. 170.

35 Darajati, M. R., \& Syafei, M. (2020). Politik Hukum Pembentukan Dua Kovenan HAM Internasional Tentang Hak Sipil Politik dan Hak Ekonomi Sosial Budaya. Syiah Kuala Law Journal, 4(2), 106-122. DOI: https://doi.org/10.24815/sklj.v4i2.16999, h. 11.

$$
\text { 255|SASI Vol. } 27 \text { No.1, Januari- Maret } 2021
$$


tidak memiliki indikasi bahwa hak-hak tersebut benar-benar dapat ditegakkan dan karenannya, negara-negara tidak mungkin dapat melanggar hak tersebut. Namun asumsi tersebut salah berdasarkan pengakuan bahwa berdasarkan ketidakterpisahan dan kesalingtergantungan semua HAM serta melalui praktik negara yang berhasil memenuhi hak Ekosob tersebut ${ }^{36}$, dengan demikian dapat dikatakan efektifnya penerapan HAM sangat bergantung dari niat baik Negara yang menjunjung tinggi tanggung jawab dan kewajiban untuk melindungi rakyatnya. Tanggung jawab dan kewajibannya seharusnya tidak bersifat dualisme atau ambiguitas, namun pengakuan, perlindungan, penghormatan dan pemajuan serta perlindungan HAM harus selaras dengan standar-standar internasional yang telah ditentukan dalam norma-norma $\mathrm{HAM}^{37}$, dalam kaitan dengan penguraian di atas, hak atas pangan sebagai HAM memang dengan jelas telah diakui dengan tegas di dalam ICESCR teristimewa di dalam Pasal 11 yang mengatur dan mengakui hak atas standar kehidupan yang memadai. Substansi Pasal 11 ini aksentuasinya pada hak untuk bebas dari kelaparan. Indikatornya diukur Hak atas pangan yang layak terwujud apabila setiap laki-laki, perempuan dan anak, sendiri atau bersama dengan orang lain memiliki akses ekonomi setiap saat ke pangan yang layak atau cara memperolehnya". Hal ini tidak mensyaratkan hak otomatis atas pangan cuma-cuma dari negara, melainkan menyerahkan bahwa negara harus menghormati hak akses ke pangan dan dengan demikian, melindungi warga negaranya dari panen paksa atau pengambilalihan lahan (selain dari hasil pertanian yang berlebihan). Lebih dari itu langkah-langkah harus diambil untuk memastikan agar perusahaan-perusahaan multi nasional dan lain-lain, tidak melanggar hak atas pangan warga negara dengan tindakan mereka.

Disamping itu Komentar Umum 12 ICESCR lebih lanjut memperkuat penyediaan hak asasi manusia atas makanan yang memadai menjadi sangat penting untuk menikmati semua hak. Landasan dasar untuk hak atas pangan yang memadai, seperti yang disusun oleh ICESCR mengatakan bahwa hak atas pangan yang memadai diwujudkan ketika setiap pria, wanita dan anak-anak, sendirian atau dalam komunitas dengan orang lain memiliki akses fisik dan ekonomi setiap saat untuk mendapatkan makanan atau sarana untuk pengadaannya dengan cara yang konsisten dengan martabat manusia. Unsur-unsur dari definisi di atas menggambarkan beberapa hal, yakni: pertama, ketersediaan makanan dalam jumlah dan kualitas yang cukup untuk memenuhi kebutuhan makanan individu, bebas dari zat-zat berbahaya dan dapat diterima dalam budaya tertentu; kedua, aksesibilitas makanan yang berkelanjutan dan yang tidak mengganggu kenikmatan hak asasi manusia lainnya ${ }^{38}$.

Menyimak dengan seksama hak-hak atas pangan yang diatur di dalam Pasal 11 dan komentar 12 ICESCR jelas memberikan pengakuan dan perlindungan terhadap semua individu atau komunitas untuk dapat mengakses pangan karena hak atas pangan ini merupakan hak yang tidak dapat dialihkan dalam kondisi apapun (non derogable rights). Oleh karena itu mengapa perlu untuk menekankan aksesbilitas fisik dan ekonomi, atas pangan. Hal ini memberikan gambaran adanya kesempatan dan hak yang seluas-luasnya bagi perempuan, laki-laki, anakanak, orang tua, kaum disabilitas, masyarakat umum ataupun masyarakat adat untuk dapat mengakses hak mereka atas pangan dengan sebaik-baiknya. Di samping itu aksesbilitas ekonomi mencirikan bahwa hak pangan mereka harus dapat dijangkau tanpa mengorbankan hak-hak mereka yang lain, yang jika pemenuhannya jauh dari yang diharapkan akan timbul kemiskinan, gisi buruk, dan biasanya ditemukan pada beberapa komunitas salah satunya masyarakat adat ${ }^{39}$. Oleh karena itu perampasan, pengambilalihan dan konversi lahan, untuk kepentingan perusahaan-perusahaan multinasional, kapitalis, dan Negara dapat berakibat terjadinya pelanggaran terhadap HAM di bidang pangan, karena tanah dan sumber-daya alam

36 Ibid. h, 119-120

37 Triyana, H. J., \& Aminoto, M. (2009). Implementasi Standar Internasional Hak Ekosob oleh Pemerintah Propinsi DIY. Mimbar Hukum, 21(3), 609-628, h. 614.

38 Sakharina, I. K. (2020). Op. Cit, h. 102.

39 https://www.komnasham.go.id/index.php/news/2018/4/19/519/tujuh-rekomendasi-pelapor-khusus-hakatas-pangan.html.

$$
\text { 256|SASI Vol. } 27 \text { No.1, Januari-Maret } 2021
$$


lainnya merupakan aksesbilitas masyarakat hukum adat yang penting untuk kelangsungan hidup mereka.

Memang harus dipahami bahwa semua HAM berkelindan satu dengan yang lainnya teristimewa dua kovenann HAM ekosob dan HAM sipil dan Politik dan karena itu secara simultan pasal ini berkait dengan hak atas perumahan. HAM atas perumahan ini merujuk kepada kenyamanan, keamanan tinggal yang maknanya diperluas sampai kepada tanah, wilayah dan semesta yang selama ini menghidupkan masyarakat adat, apapun bentuknya bukan menjadi soal, tidak harus dipahami secara sempit, dari kacamata manusia modern. Dengannya tidak dapat dibenarkan adanya tindakan penggusuran, pemindahan secara paksa, hanya karena tanah, hutan, dan wilayahnya hendak dieksploitasi baik oleh Negara maupun perusahaan mulitinasional dan lainnya, ada cara-cara yang lebih persuasif dan lebih manusiawi, karena hutan, tanah, air, wilayah, semesta adalah rumah tinggal yang menyediakan kebutuhan jasmani dan rohani mereka dan dirawat dengan nilai-nilai keseimbangan antara material dan spiritual. Meneliti dari berbagai tindakan dan kasus yang menghinggapi masyarakat hukum adat atas wilayah, tanah, air dan hak-hak mereka yang lain, kelihatannya hukum internasional telah mengadopsi kepentingan dan hak-hak mereka secara menguat, namun demikian secara implementatif lemah.

Jeremy Bentham dengan mashab Utilitarian menekankan hukum harus dapat memberikan kemanfataan atau kebahagiaan bagi sebanyak-banyaknya orang, the greatest happiness of the greatest number (kebahagiaan terbesar untuk mayoritas) ${ }^{40}$. Ukuran kebahagiaan bagi mereka masyarakat hukum adat tidaklah dapat menggunakan ukuran kebanyakan orang. Standar ukuran kebahagiaan mereka yang mayarakat adat, yang terkatagori minoritas, rentan, cukuplah mereka tidak diganggu, cukuplah mereka dihargai dan dihormati beserta tatanan hidupnya. Olehnya itu tindakan menggusur, memarginalisasi, menyingkirkan mereka dari alam semesta baik berupa tanah, air, wilayah, dan semua yang melekat di dalamnya berarti kebahagiaan mereka telah dirampas dengan yang namanya kerakusan, keserakahan, dan kepentingan segolongan orang. Bagi mereka masyarakat hukum adat kebahagiaan adalah ketika mereka dapat menjaga keseimbangan hidupnya dengan alam semesta dengan sisitem nilai, dan norma dengan yang "maha tertinggi", dalam pandangan dan keyakinan mereka.

Dalam konteks yang demikian, perlu untuk meletakan hukum dan tujuannya berdasarkan pada nilai dan norma hukum adat. Secara umum tujuan hukum yang dapat diterima pada setiap ruang, waktu, tempat dan semua orang adalah hukum yang menciptakan kebaikan, ketertiban, dan kesejahteraan. Kesejahteraan akan selalu a contrario dengan kebebasan dari kemelaratan

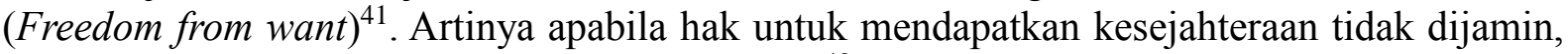
maka implikasi yang muncul adalah kemelaratan ${ }^{42}$, untuk mewujudkan kebahagiaan individu dan masyarakat maka hukum harus mencapai empat tujuan, yaitu memberi sumber nafkah hidup (subsistence), kecukupan (abundance), keamanan (security), dan kesetaraan (equality) ${ }^{43}$. Hal ini terkait erat dengan hak masyarakat adat atas pangan, untuk dapat hidup, dalam kesetaraan tidak didiskriminasi, diberikan hak untuk berpartisipasi, hak untuk menyetujui sesuatu hal apabila terkait dengan hak-hak mereka, hak untuk menikmati semesta dengan semua yang telah disediakan "Yang Maha Tertinggi" bagi mereka, tanpa terusik, tergusur dari semesta yang telah menghidupkan mereka secara turun temurun dengan alam yang limpah ruah dengan berkah.

40 Latipulhayat, A. (2015). Khazanah: Jeremy Bentham. Padjadjaran Journal of Law, 2(2), 413-425, h. 419.

41 Na'a, S. (2014). Sebuah Kontemplasi Tentang Klasifikasi Hak-hak Asasi Manusia. Jurnal Wawasan Yuridika, 22(1), 124-134, h. 132.

42 Fios, F. (2012). Keadilan hukum Jeremy Bentham dan relevansinya bagi praktik hukum kontemporer. Humaniora, 3(1), 299-309. DOI: https://doi.org/10.21512/humaniora.v3i1.3315, h. 302.

${ }^{43}$ Latipulhayat, A. (2015). Op. Cit, h. 418. 


\section{Implikasi Hukum Ketahanan Pangan Masyarakat Hukum Adat yang tidak Terpenuhi Pada Masa Pandemi Covid-19}

Di dalam Konstitusi Negara Republik Indonesia dengan jelas dan tegas telah merumuskan dan mengakomodir hak-hak asasi manusia Indonesia, sebagaimana diatur mulai dari Pasal 27 sampai dengan Pasal 34 UUD 1945. Pengaturan terhadap hak-hak asasi manusia di dalam konstitusi merupakan sebuah pengakuan yang ditetapkan dalam sumber hukum tertinggi bagi Negara hukum seperti Indonesia ${ }^{44}$. Hak atas pangan merupakan kewajiban konstitusional Negara. Hal ini sebagaimana telah dirumuskan didalam Pasal 28I ayat (4); perlindungan, pemajuan, penegakan, dan pemenuhan hak asasi manusia adalah tanggung jawab Negara, terutama pemerintah. Teks di dalam konstitusi ini hendak mempertegas tujuan dibentuknya Negara Republik Indonesia yang dituangkan di dalam Pembukaan UUD 1945; melindungi seluruh tumpah darah Indonesia, memajukan kesejahteraan umum mencerdaskan kehidupan bangsa dan ikut melaksanakan ketertiban dunia yang berdasarkan pada kemerdekaan, perdamaian abadi dan keadilan sosial. Tujuan hidup bernegara ini akan terimplementasi melalui kewajibannya untuk memenuhi hak-hak sipil, politik, sosial ekonomi dan budaya setiap anggota masyarakat.

Pangan sebagai salah satu hak mendasar dan merupakan HAM yang terus diperdebatkan karena terkait dengan begitu banyak soal yang membelit, dengan mengadopsi pendapat dari Mutaqin dalam tulisan Gusti Nur A.Shabia, dikatakan hak atas pangan dan gizi merupakan hak yang diwujudkan ketika setiap laki-laki, perempuan, dan anak, secara individual ataupun dalam komunitas bersama orang lain, memiliki akses fisik dan ekonomi setiap saat terhadap pangan yang layak, atau ketika mereka memiliki sarana untuk memperoleh makanan. Hak atas pangan dan gizi ini merupakan hak yang terlahir sebagai kebutuhan dasar manusia sebagai makhluk hidup dan merupakan kewajiban mengikat yang dikukuhkan oleh hukum internasional. ${ }^{45}$ Dari definisi di atas, bisa dikritisi bahwa hak atas pangan dan gizi memperhatikan tiga elemen dasar yakni ${ }^{46}$ :

1) Memperhatikan pemenuhan di setiap lapisan gender, usia, kelas, tanpa kecuali;

2) Memperhatikan akses pangan di tingkat individu maupun kolektif, karena fenomena kelaparan dan malnutrisi tidak hanya terjadi secara perseorangan, tetapi bisa ditemukan dalam tingkatan rumah tangga hingga secara kolektif dalam suatu unit masyarakat;

3) Menekankan bahwa akses terhadap pangan juga memperhatikan sarana untuk memperolehnya dan ketika berbicara sarana, maka kita akan berbicara pula soal kepemilikan dan penguasaan.

Elemen-elemen yang dikemukakan di atas sangat terkait dengan kewajiban Negara untuk melaksanakan perannya dalam membangun ketahanan pangan, kedaulatan pangan maupun kemandirian pangan. Istilah ketahanan pangan digunakan sebagai istilah umum secara global. Ini digunakan dalam banyak instrumen internasional seperti konvensi, perjanjian, protokol dan perjanjian. Secara sederhana ketahanan pangan berarti makanan yang cukup untuk dimakan orang dan dihasilkan dari sistem pangan berkelanjutan. FAO menggambarkan ketahanan pangan sebagai situasi yang ada ketika semua orang, setiap saat, memiliki akses fisik, sosial dan ekonomi ke makanan yang cukup, aman dan bergizi yang memenuhi kebutuhan makanan mereka dan preferensi makanan untuk kehidupan yang aktif dan sehat. ${ }^{47}$

44 Likadja, J. A. C. (2015). Memaknai "Hukum Negara (Law Through State)" dalam Bingkai "Negara Hukum (Rechtstaat)". Hasanuddin Law Review, 1(1), 75-86. DOI: http://dx.doi.org/10.20956/halrev.v1i1.41, h. 76.

45 Shabia, G. N. A. (2021). Hak atas Pangan Dan Gisi, Sebuah Pengantar. Jurnal Hak Atas Pangan dan Gizi, 1(Januari), 1-6, h. 1.

46 Ibid.

47 Zuhra, A. (2019). Op. Cit. h. 106-107

$$
\text { 258|S A S I Vol. } 27 \text { No.1, Januari- Maret } 2021
$$


Sekedar sebagai perbandingan, pangan di dalam Undang-Undang No 7 Tahun 1996 merupakan kebutuhan dasar dan bagian dari HAM yang bertujuan bagi peningkatan kehidupan yang layak bagi warga Negara. Konsep ketahanan pangan menurut Undang-undang Nomor 7 tahun 1996 adalah kondisi terpenuhinya pangan bagi rumah tangga yang tercermin dari tersedianya pangan yang cukup, baik jumlah maupun mutunya, aman, merata, dan terjangkau. ${ }^{48}$ Sementara di dalam Bab I Ketentuan Umum UU No 18 Tahun 2012 tentang Pangan pada Bab I Pasal 1 butir dijelaskan mengenai Ketahanan pangan dipahami sebagai kondisi terpenuhinya pangan bagi negara sampai dengan perseorangan, yang tercermin dari tersedianya pangan yang cukup, baik jumlah maupun mutunya, aman, beragam, bergizi, merata, dan terjangkau serta tidak bertentangan dengan agama, keyakinan, dan budaya masyarakat, untuk dapat hidup sehat, aktif, dan produktif secara berkelanjutan.

Mengamati konsep ketahanan pangan yang tertuang baik dalam UU No 7 tahun 1996 yang pernah berlaku dan UU No 18 tahun 2012 yang merupakan hukum positif sekarang ini terbaca dengan terang dan jelas ada perbedaan yang cukup menonjol. UU No 7 tahun 1996 sangat sederhana dan ruang lingkup pengertiannya terbatas dibandingkan dengan UU No 18 Tahun 2012 yang sangat luas cakupannya. Secara substantif UU Pangan yang sekarang scope pengaturannya mulai dari ketahanan pangan perseorangan sampai ke Negara dengan aksesbilitas fisik, sosial, ekonomi kesehatan, keyakinan dan budaya dan sifatnya harus berkelanjutan tidak terputus, untuk memenuhi target dan tujuan seperti yang diharapkan di UU Pangan, maka tidak bisa tidak ketahanan pangan harus seyogyanya beriringan dengan kedaulatan pangan dan kemandirian pangan, sehingga tujuan akhir terwujudnya ketahanan pangan dapat terealisasi. Di dalam UU Pangan, kedaulatan pangan adalah hak negara dan bangsa yang secara mandiri menentukan kebijakan Pangan yang menjamin hak atas Pangan bagi rakyat dan yang memberikan hak bagi masyarakat untuk menentukan sistem Pangan yang sesuai dengan potensi sumber daya local. Sementara itu kemandirian pangan di dalam UU ini didefinisikan sebagai kemampuan negara dan bangsa dalam memproduksi pangan yang beraneka ragam dari dalam negeri yang dapat menjamin pemenuhan kebutuhan pangan yang cukup sampai di tingkat perseorangan dengan memanfaatkan potensi sumber daya alam, manusia, sosial, ekonomi, dan kearifan lokal secara bermartabat .

Lukman Adam dalam hasil kajiannya mengungkapkan jika dilihat dari konsep, maka kedaulatan pangan berbeda dengan ketahanan pangan, namun secara prinsipil dalam praktek memiliki relasi yang kuat dan saling ketergantungan, dalam ulasanya dikatakan Prinsip kedaulatan pangan berbeda dengan ketahanan pangan yang tidak mempedulikan asal produksi pangan. Sementara Kedaulatan pangan cenderung menjunjung tinggi hak setiap warga dan masyarakat lokal sebagai satu kesatuan produksi, distribusi, dan pemenuhan kebutuhan pangan di atas semua kepentingan lain. Selanjutnya dia mengatakan, konsep kedaulatan pangan tidak bertentangan dengan prinsip ketahanan pangan. Upaya membangun ketahanan pangan tanpa diikuti dengan upaya menegakkan kedaulatan pangan akan melahirkan persoalan sosial baru, seperti ketergantungan terhadap pangan impor dan rendahnya produktivitas petani. ${ }^{49}$

Pemerintah sebagai personifikasi Negara dalam melaksanakan kewajibannya dalam penyelenggaraan pangan tidak terlepas dari prinsip-prinsip HAM yakni menghormati (to respect), melindungi (to protect), dan memenuhi (to fulfill), dalam implementasi HAM atas pangan ini, kewajiban Negara dalam menerapkan ketiga langkah tersebut merupakan rangkaian yang saling berkaitan, dengan meminjam konsep pikir dari Hernandi Affandi yang mengatakan ketiga langkah tersebut merupakan proses dari hulu sampai ke hilir. Artinya, bahwa langkah pertama akan membawa dampak pada langkah kedua, seterusnya langkah kedua akan

48 Purwaningsih, Y. (2008). Ketahanan Pangan: Situasi, Permasalahan, Kebijakan, dan Pemberdayaan Masyarakat. Jurnal Ekonomi Pembangunan: Kajian Masalah Ekonomi dan Pembangunan,9(1), 1-27. DOI: https://doi.org/10.23917/jep.v9i1.1028, h. 2.

49 Adam, L. (2014). Kinerja Ekonomi Pangan Nasional: Dinamika dan Reformulasi Kebijakan. Jurnal Ekonomi \& Kebijakan Publik, 5(2), 173-192. http://jurnal.dpr.go.id/index.php/ekp/article/view/82, h. 175-175. 
mempengaruhi langkah ketiga. Dengan demikian, sebelum langkah ketiga harus didahului oleh langkah kedua, dan sebelum langkah kedua harus didahului oleh langkah pertama. Oleh karena itu, langkah terakhir akan menjadi puncak dari bentuk pertama dan kedua. ${ }^{50}$

Didalam berbagai instrument hukum internasional, kewajiban Negara untuk melaksanakan HAM sudah merupakan keharusan apakah dengan segera atau dengan bertahap, untuk HAM atas pangan yang merupakan bagian dari HAM ICESCR pemenuhannya memang secara bertahap tetapi berkelanjutan. Hal tersebut ditunjukan dengan langkah-langkah di atas, seperti hak untuk melindungi dibuktikan dengan kewajiban Negara menetapkan regulasi untuk mengatur dan mengurus hak pangan.

Pada gilirannya kewajiban Negara untuk memenuhi adalah dengan menyediakan dan memfasilitasi hak atas pangan agar dapat terpenuhi bagi masyarakat dalam situasi dan kondisi apapun. Terkait dengan kewajiban Negara, maka ada prinsip umum dari hak atas pangan yang harus dicermati oleh Negara karena pada gilirannya akan berdampak pada ketahanan pangan masyarakat secara umum dan masyarakat adat secara khusus. Prinsip umum dari hak atas pangan tersebut antara lain: Pertama, bahwa pemenuhan hak atas pangan rakyat adalah tanggung jawab negara. Kedua, ketahanan pangan hanya bisa dicapai jika ada kecukupan lahan bagi produksi pangan, distribusi yang baik, produksi pangan dan ketersediaan pangan yang dikonsumsi. ${ }^{51}$

Menyimak kewajiban Negara Indonesia dalam mengimplementasikan HAM atas pangan, kecenderungannya adalah diskriminatif terhadap masyarakat adat. Hal mana tercermin dari berbagai tindakan yang dilakukan terhadap tanah, wilayah dan sumber daya alam dari masyarakat adat yang dirampas, dikonversi bagi kepentingan investor. Negara telah melakukan pelanggaran bagi HAM atas pangan dari masyarakat adat. Negara Indonesia memperlakukan masyarakat adat dengan mengakui identitas yang satu dan menyingkirkan yang lain. Dalam banyak kasus, identitas yang lain itu seringkali berhubungan dengan akumulasi modal-modal asing untuk mengeksploitasi sumber daya alam ${ }^{52}$ Pada gilirannya kedaulatan pangan tidak mungkin akan tercapai mengingat ketahanan pangan masyarakat adat sangat lemah dan rapuh akibat dominannya kepentingan Negara bagi para pemodal. Hal ini mengandung arti Negara telah melakukan pengabaian, penelantaran terhadap hak-hak masyarakat adat atas pangan dan jika hal ini dilakukan secara terus menerus, maka pelanggaran tersebut dapat disamakan dengan pemusnahan generasi secara laten (silent genocide) ${ }^{53}$ Tanah, wilayah, sumber daya alam adalah identik dengan HAM masyarakat adat atas hidup, dan pangan adalah bagian dari hak mereka untuk keberlanjutan hidup.Tanah bagi mereka adalah raison d'etre bagi keseluruhan eksistensi hidup mereka. ${ }^{54}$

UU No 18 tahun 2012 mendefiniskan pangan sebagai segala sesuatu yang berasal dari sumber hayati produk pertanian, perkebunan, kehutanan, perikanan, peternakan, perairan, dan air, baik yang diolah maupun tidak diolah yang diperuntukkan sebagai makanan atau minuman bagi konsumsi manusia, termasuk bahan tambahan pangan, bahan baku pangan, dan bahan lainnya yang digunakan dalam proses penyiapan, pengolahan, dan/atau pembuatan makanan

50 Affandi, H. (2017). Tanggungjawab Negara dalam Pemenuhan Hak Atas Pendidikan Menurut UndangUndang Dasar Tahun 1945. Jurnal Hukum: Positum, 1(2), 218-243, h. 235.

51 Naiggolan, K. (2005). Pengaturan \& Realisasi Pemenuhan Hak Atas Pangan Yang Layak. Jakarta: Komnas HAM. Dalam, Sakharina, I. K. (2020). Op. Cit, h. 373.

52 Steni, B. (2009). Politik Pengakuan Masyarakat Adat Atas Tanah Dan Sumber Daya Alam: dari Hindia Belanda hingga Indonesia Merdeka” dalam Sulistyowati Irianto (Ed), Hukum Yang Bergerak Tinjauan Antropologi Hukum. Jakarta: Yayasan Obor Indonesia, h. 220.

53 Bina Desa. (2016). Kewajiban Negara dalam Hak Atas Pangan. https://binadesa.org/kewajiban-negaradalam-hak-atas-pangan/.

54 Wattimena, J.A.Y. (2013). Prinsip-Prinsip Penanaman Modal Asing Dan Implementasinya Pada Masyarakat Hukum Adat. In Kumpulan Tulisan Dosen-Dosen Fakultas Hukum Universitas Pattimura. Ambon: Anugrah Sejati, h. 96.

$$
\text { 260|SASI Vo1. } 27 \text { No.1, Januari-Maret } 2021
$$


atau minuman. Pemanfaatan pangan atau konsumsi pangan dan gizi akan menghasilkan sumber daya manusia yang berkualitas sebagai salah satu faktor penentu keberhasilan pembangunan. Hal itu dilakukan melalui pemenuhan asupan pangan yang beragam, bergizi seimbang, serta pemenuhan persyaratan keamanan pangan, mutu pangan, dan gizi pangan. Perwujudan ketersediaan pangan yang berbasis pada pemanfaatan sumber daya lokal secara optimal dilakukan dengan penganekaragaman pangan dan pengutamaan produksi pangan dalam negeri. Pewujudan keterjangkauan pangan dari aspek fisik dan ekonomi dilakukan melalui pengelolaan stabilisasi pasokan dan harga pangan pokok, pengelolaan cadangan pangan pokok, dan pendistribusian pangan pokok

Hal yang digambarkan sebagai suatu kondisi ideal yang digambarkan UU Pangan, dalam realisasinya selalu akan berhadapan dengan elemen-elemen dasar dari pemenuhan hak-hak asasi manusia yakni; ketersediaan (availability), kualitas (quality) dan mudah dicapai (accessibility). Termasuk mudah dicapai i) secara fisik (physical accessibilty),ii) kemampuan pengadaan, (economic accessibility) dan iii) non diskriminasi (non discrimination), ${ }^{55}$ ditambah dengan tanggungjawab Negara (state responsibility) yang cenderung masih lemah karena berorientasi kepada kepentingan negara daripada masyarakat adat .

Elemen-elemen dasar dari pemenuhan hak asasi manusia atas pangan ini apabila dikondisikan dalam masa pandemik covid-19 dapat dibilang sebagai masalah yang cukup krusial. Hal ini mengingat penerapan lock down, physical distancing, dan PSBB, dengan pembatasan-pembatasan baik skala besar, ataupun transisi sebagai mekanisme yang digunakan untuk memutus mata rantai penyebaran ternyata memberikan dampak yang signifikansi bagi pemenuhan hak-hak hidup masyarakat.

Masyarakat adat sebagai salah satu komunitas yang ada di Indonesia, kebanyakan mendiami dan menghuni wilayah yang dapat dikatakan terpencil dan jauh ke polosok-pelosok daerah. Untuk menjangkau wilayah mereka juga merupakan persoalan tersendiri apalagi dalam masa pandemic seperti ini. Aksesbilitas fisik, sosial, ekonomi masyarakat adat untuk memperoleh pangan menjadi tantangan tersendiri.

Pangan lokal sebagai sumber kebutuhan hidup dapat menjadi salah satu solusi atau alternatif untuk menjawab kebutuhan pangan mereka. Namun sebagaimana dijelaskan dalam UU No 18 tahun 2012 tentang pangan sebagai kebutuhan dasar manusia harus senantiasa tersedia secara cukup, aman, bermutu, bergisi dan beragam dengan harga yang terjangkau oleh daya beli masyarakat. Tentunya pemenuhan pangan masyarakat adat bukan sekedar soal tersedianya pangan local sebagai alternatif, tetapi ada permasalahan yang lebih krusial yakni tanah-tanah dan lahan mereka yang telah dikuasai oleh para investor untuk perkebunan, HPH, pengelolaan tambang, dan lain sebagainya. Kondisi ini sebagaimana dijumpai dalam penelitian Badan pekerja Harian (BPH), Aliansi masyarakat Adat Nusantara (AMAN), Bengkulu, Deftris yang mengungkapkan "perkebunan-perkebunan skala besar perparah ancaman krisis pangan dalam pandemik covid-19. ${ }^{56}$ Penemuan ini seolah mewakili kondisi yang sama di mana masyarakat adat bermukim

Pangan bagi masyarkat adat saat ini masih dapat terpenuhi dengan pangan lokal. Akan tetapi pemenuhan pangan bagi masyarakat adat di ketiga negeri dan negeri di sekitarnya, mungkin belum sesuai dengan substansi atau pun makna pangan sesuai UU No 18 Tahun 2012. Yang secara kualitatif harus terpenuhi elemen aman, beragam, bergizi, merata, dan terjangkau, di tengah situasi mewabahnya covid-19. Jadi ketersediaan pangan bukan soal tersedianya pangan semata hanya untuk dikomsumsi karena kondisi riil yang sementara dihadapi, tetapi ketersediaan pangan juga harus seimbang dengan kebutuhan tubuh berupa gizi, beragam, dan dapat terjangkau untuk dibeli oleh masyarakat. Sebuah kesia-siaan apabila apabila masyarakat

55 El-Muhtaj, M. (2013). Op .Cit, h. 134.

$56 \mathrm{http} / / / w w w . a m a n . o r . i d / 2020 / 06 /$ pernyataan-sikap-aman-kalimantan-tengah-terkait-rencana-food-estatecetak-sawah/BENGKULU

$$
\text { 261|SASI Vo1. } 27 \text { No.1, Januari-Maret } 2021
$$


tidak mampu menjangkaunnya karena kondisi dan situasi yang sulit seperti bencana pandemik covid-19 ini, yang juga tak mungkin diprediksi kapan berakhirnya. Padahal ini berkorelasi dengan keberlanjutan hidup. Keberlanjutan hidup dan ketahanan pangan bagaikan dua sisi mata uang yang tidak dapat dilepaspisahkan. Olehnya itu menjadi tanggung jawab Negara untuk memberdayakan kehidupan masyarakatnya bukan malah menegasikannya dengan memberikan hak-hak keiistimewaan bagi para kapitalis dan pemodal dan malah menelantarkan rakyatnya. Bukankah kehadiran Negara adalah untuk memberikan kesejahtraan bagi rakyatnya bukan sebaliknya menyengsarakan. Garner dalam Samijo mengungkapkan setidaknya ada terdapat tiga tujuan hidup bernegara yang i) pemeliharaan perdamaian, ketertiban, keamanan dan keadilan, ii) Negara harus menghadirkan kesjatraan bersama dan kemajuan bersama dan iii) tujuan Negara untuk memajukan peradaban dan kemajuan Negara. ${ }^{57}$

Sejatinya Negara dalam hal ini pemerintah bertanggungjawab memberdayakan kehidupan warga masyarakatnya tidak terkecuali masyarakat adat, yang mendasarkan hidupnya pada tanah dan sumber daya alamnya. Problemnya adalah pengaturan wilayah adat dalam konsep yang didefinisikan oleh Negara hanya dikonotasikan sebagai kewenangan untuk memanfaatkan. Padahal wilayah adat yang lebih dikenal dengan istilah hak ulayat termasuk di dalamnya kewenangan untuk mengatur dan menguasai. Kewenangan untuk mengatur dan menguasai oleh Negara sengaja atau tidak sengaja dihilangkan agar Negara juga dapat memberikan keleluasaan bagi para pemodal/kapitalis untuk mengeruk dan menguasai hak-hak masyarakat adat sehingga tidak bersisa, yang ditinggalkan hanya kerusakan lingkungan hidup, ketidakberdayaan dan kehilangan mata pencaharian ${ }^{58}$. Padahal demi dan untuk mempertahankan hidup, mata pencaharian merupakan salah satu cara untuk meningkatkan standar hidup, terkait dengan ketersediaan pangan dan ketahanan pangan. Hal ini sebagaimana ditegaskan dalam Resolusi Majelsi Umum PBB 3348 (XXIX) tertanggal 17 Desember 1974 yang mengesahkan Universal Declaration on the Eradiction of hunger and Malnutrition. Deklarasi ini menyatakan bahwa setiap orang harus bebas dari kelaparan dan kekurangan gizi dan hal ini merupan inalienable rights.59

Di dalam masa pandemic covid-19 ini, Negara mesti berhati-hati untuk memasukan para kapitalis untuk mengelola sumber-sumber daya alam dan tanah-tanah masyarakat adat, mengingat kondisi ini rentan dengan ketidakstabilan ekonomi yang berdampak terhadap ketidakstabilan nasional. Kondisi kemiskinan, kemelaratan, bencana kelaparan dapat mengancam kehidupan negri ini sebagai akibat ketiadaan keberlanjutan produksi sebagai akibat kekosongan dan ketiadaan lahan untuk produksi pertanian. Kegagalan Negara untuk melaksanakan tanggung jawab atau kewajiban posititifnya dalam pemenuhan hak atas pangan sebagai bagian dari ketahanan pangan perseorangan atau pun masyarakat akan berakibat Negara melakukan pelanggarann atas ekonomi, sosial dan budaya. Apalagi Negara Indonesia telah meratifikasi Konvensi ICESCR dengan UU No 11 tahun 2005.

Penerapan konvensi ICESCR ini sebagai wujud HAM akan didasarkan kepada prinsipprinsip Limburg (Limburg Principles) yang menjadi pedoman bagaimana seharusnya kewajiban tersebut dilanggar oleh suatu Negara. (violations of covenant obligations). Prinsipprinsip tersebut antara lain: ${ }^{60}$

1) Negara gagal mengambil langkah -langkah yang wajib dilakukannya;

2) Negara gagal menghilangkan rintangan secara cepat di mana Negara tersebut berkewajiban untuk menghilangkannya;

57 Samijo. (1996). Ilmu Negara. Bandung, Armico, h. 220

$58 \mathrm{https} / /$ nasional.kompas.com/read/2019/12/10/09145461/nasib-masyarakat-adat-yang-terancaminvestasi-hingga-kriminalisasi?page $=$ all.

59 El-Muhtaj, M. (2013). Op .Cit, h. 122.

60

262|S A S I Vo1. 27 No.1, Januari- Maret 2021 
3) Negara gagal melaksanakan tanpa menunda lagi suatu hak yang diwajibkan pemenuhannya dengan segera;

4) Negara dengan sengaja gagal memenuhi sutu standar pencapaian yang umum diterima secara internasional

5) Negara menerapkan pembatasan terhadap suatu hak diakui dalam kovenan

6) Negara dengan sengaja menunda atau menghentikan pemenuhannya secara bertahap dari suatu hak;

7) Negara gagal untuk mengajukan laporan yang diwajibkan oleh Kovenan.

Kondisi mewabahnya covid-19 yang mengglobal dan yang tidak diketahui kapan berakhirnya, Indonesia mengalami dampaknya yang luar biasa baik dari aspek kesehatan maupun aspek ekonomi yang tak kurang parahnya. Geografis Indonesia yang terdiri dari belasan ribu pulau dengan struktur masyarakat yang tersegregasi di pulau-pulau kecil terpencil dengan rentang kendali pada wilayah laut menjadi persoalan yang tidak mudah berhadapan dengan covid-19. Pembatasan-pembatasan sosial sebagai sarana untuk melakukan pemutusan mata rantai covid-19 ternyata berimplikasi terhadap pemenuhan kebutuhan pangan masyarakat adat.

Parameter-parameter yang dirumuskan dalam Prinsip-prinsip Limburg menjadi standar normative untuk mengukur atau mengidentifikasi tanggung jawab Negara terhadap pemenuhan hak atas pangan yang merupakan suatu kesatuan dalam pemahaman konsep ketahanan pangan. Olehnya itu Negara dapat dituntut ketika tidak mampu dan tidak sanggup untuk melaksanakan pemenuhan hak atas pangan masyarakat adat apalagi secara sengaja dalam bentuk tindakan mengurangi, bahkan menghilangkan melalui berbagai kebijakan untuk menghindari pemenuhannya terhadap kewajiban yang mesti ditunaikan.

Muhammad Ashri dalam tulisannya tentang tanggung jawab Negara dengan mengutip dari Yudabakti mengatakan tanggungjawab Negara berhubungan erat dengan suatu keadaan dimana prinsip-prinsip fundamental hukum internasional menegaskan bahwa Negara atau pihak yang dirugikan memiliki hak untuk mendapatkan ganti atas kerugian yang di deritanya. Karena itu, tanggung jawab Negara bergantung kepada penentuan atas dasar apa dan pada situasi bagaimana Negara dapat dianggap melakukan kesalahan dan karenannya ia bertanggungjawab. Malahan dipertegas olehnya dengan mengutip pendapat Hakim Huber dalam perkara The Spanish zone Of Marrocco claims (1925) mengemukakan bahwa tanggung jawab merupakan konsekwensi yang wajar dari adanya hak, dan sepanjang hak itu mempunyai sifat hukum internasional ia akan melahirkan tanggung jawab internasional yang mengakibatkan adanya keharusan untuk mengadakan perbaikan.

HAM yang tertuang di dalam ICESCR memang dalam rangka pemenuhannya berdasarkan kepada progressive realization, dalam hal pemenuhannya dilaksanakan secara berangsur-atau bertahap, tetapi pemenuhan hak atas pangan adalah sesuatu yang bersifat mendesak. Makanan, air, dan udara adalah tiga unsur penting dalam kehidupan manusia, ini yang disebut tiga derajat kehidupan manusia. Derajat kepentingan dari tiga hal tersebut dapat disimpulkan dari pernyataan bahwa seorang manusia dapat bertahan tiga minggu tanpa makanan, tiga hari tanpa air dan tiga menit tanpa udara ${ }^{61}$. Dari tiga hal tersebut, udara dan air adalah pemberian alam, namun pangan harus diproduksi. Pangan menjadi salah satu kebutuhan utama manusia yang dapat diakses dengan mudah baik secara fisik, ekonomi dan sosial. Ketidakhadiran Negara dianggap sebagai pelenggaran HAM sebagaimana dijelaskan dalam prinsip-prinsip Limburg, dengan demikian sekalipun covid 19 menjadi ancaman, akan tetapi kehadiran Negara sangat dibutuhkan untuk menjawab permasalahan ketahanan pangan masyarakat adat.

${ }^{61}$ Zuhra, A. (2019). Op. Cit, h. 99.

263|SASI Vo1. 27 No.1, Januari - Maret 2021 


\section{P E N U T U P}

Berdasarkan hasil penelitian ketahanan pangan masyarakat adat sangat terdampak pada saat pandemic covid -19. Apalagi tanah dan wilayah masyarakat adat yang telah berada dibawah penguasaan perusahaan-perusahaan yang mengeksploitasi sumber-sumber daya alam mereka. Tentunya hal ini akan turut memperparah pemenuhan hak-hak mereka atas kebutuhan pangan. Prinsip dasarnya Ketahanan pangan dan kedaulatan pangan masyarakat adat atas tanah tidak dikonversi atau diambil alih oleh Negara dan perusahaan-perusahan multinasional. Di dalam instrument hukum internasional dan nasional telah merumuskan tanggungjawab Negara untuk melakukan perlindungan dan pemenuhan atas hak pangan mereka. Berbagai situasi dan kondisi yang merintangi pelaksanaan tanggung jawab Negara harus dapat dicarikan jalan keluarnya.. Jika Negara tidak dengan segera melakukan tanggungjawabnya terkait hak-hak mendasar seperti hak atas pangan ini, maka Negara akan dianggap telah melakukan pelanggaran dan menurut hukum internasional dapat dituntut.

\section{DAFTAR PUSTAKA}

\section{Jurnal}

[1] Adam, L. (2014). Kinerja Ekonomi Pangan Nasional: Dinamika dan Reformulasi Kebijakan. Jurnal Ekonomi \& Kebijakan Publik,5(2), 173-192. http://jurnal.dpr.go.id/index.php/ekp/article/view/82.

[2] Affandi, H. (2017). Tanggungjawab Negara dalam Pemenuhan Hak Atas Pendidikan Menurut Undang-Undang Dasar Tahun 1945. Jurnal Hukum: Positum, 1(2), 218-243.

[3] Ashri, M. (2008). Gugatan Warga dan Tanggung Jawab Nagara Dalam Pemenuhan Hak atas Pendidikan. Indonesian Journal of International Law, 5(2), 295-318.

[4] Darajati, M. R., \& Syafei, M. (2020). Politik Hukum Pembentukan Dua Kovenan HAM Internasional Tentang Hak Sipil Politik dan Hak Ekonomi Sosial Budaya. Syiah Kuala Law Journal, 4(2), 106-122. DOI: https://doi.org/10.24815/sklj.v4i2.16999.

[5] Fios, F. (2012). Keadilan hukum Jeremy Bentham dan relevansinya bagi praktik hukum kontemporer. Humaniora, 3(1),

299-309. DOI: https://doi.org/10.21512/humaniora.v3i1.3315.

[6] Kennedy, P. S. J., Tampubolon, E., \& Fakhriansyah, M. (2020). Analisis Strategi Lockdown Atau Pembatasan Sosial Dalam Menghambat Penyebaran Covid-19: Sebuah Tinjauan Teoritis. Image: Jurnal Riset Manajemen, 9(1), 48-64.

[7] Latipulhayat, A. (2015). Khazanah: Jeremy Bentham. Padjadjaran Journal of Law, 2(2), 413-425.

[8] Likadja, J. A. C. (2015). Memaknai "Hukum Negara (Law Through State)" dalam Bingkai "Negara Hukum (Rechtstaat)". Hasanuddin Law Review, 1(1), 75-86. DOI: http://dx.doi.org/10.20956/halrev.v1i1.41.

[9] Loetan, S. (2003). Millennium Development Goal (MDG) dan Program Pembangunan Nasional di Indonesia. Jurnal Hukum Internasional, 1(1), 60-77.

[10] Mulyasari, G. (2016). Kajian Ketahanan Pangan dan Kerawanan Pangan di Provinsi Bengkulu. Jurnal AGRISEP Kajian Masalah Sosial Ekonomi Pertanian dan Agribisnis, 15(1), 83-90.

[11] Na'a, S. (2014). Sebuah Kontemplasi Tentang Klasifikasi Hak-hak Asasi Manusia. Jurnal Wawasan Yuridika, 22(1), 124-134.

[12] Nugroho, O. C., \& Kav, J. H. R. S. (2018). Konflik Agraria Di Maluku Ditinjau Dari Perspektif Hak Asasi Manusia. Jurnal HAM, 9(1), 87-101.

[13] Purwaningsih, Y. (2008). Ketahanan Pangan: Situasi, Permasalahan, Kebijakan, dan Pemberdayaan Masyarakat. Jurnal Ekonomi Pembangunan: Kajian Masalah Ekonomi dan Pembangunan, 9(1), 1-27. DOI: https://doi.org/10.23917/jep.v9i1.1028.

[14] Sakharina, I. K. (2020). Hak Atas Pangan di Masa Pandemi Coronavirus Disease Covid264|S A S I Vo1. 27 No.1, Januari - Maret 2021 
19. Jurnal Legislatif, 367-384.

[15] Shabia, G. N. A. (2021). Hak atas Pangan Dan Gisi, Sebuah Pengantar. Jurnal Hak Atas Pangan dan Gizi, 1(Januari), 1-6.

[16] Sanny, H., Pieris, J., \& Foekh, D. Y. P. (2021). Hak Asasi Manusia, Demokrasi dan Pancasila. to-ra, 7(Special Issue), 142-156.

[17] Syofyan, A. (2012). Perlindungan Hak-Hak Masyarakat Adat Menurut Hukum Internasional. Fiat Justisia: Jurnal Ilmu Hukum, 6(2). https://doi.org/10.25041/fiatjustisia.v6no2.326.

[18] Tarigan, J. P. (2017). Akomodasi Politik Hukum di Indonesia terhadap Hak Asasi Manusia Berdasarkan Generasi Pemikirannya. Jurnal Konstitusi, 14(1), 168-187. DOI: https://doi.org/10.31078/jk1418.

[19] Triyana, H. J., \& Aminoto, M. (2009). Implementasi Standar Internasional Hak Ekosob oleh Pemerintah Propinsi DIY. Mimbar Hukum, 21(3), 609-628, h. 614.

[20] Yuliarso, K. K., \& Prajarto, N. (2005). HAM di Indonesia: Menuju'Democratic Governances'. Jurnal Ilmu Sosial dan Ilmu Politik, 8(3), 291-308. DOI: https://doi.org/10.22146/jsp.11046.

[21]Zuhra, A. (2019). Ketahanan Pangan Dan Tanggung Jawab Negara Saat Konflik Bersenjata: Sebuah Tinjauan Hukum. terAs Law Review, 1(1), 98-126.

\section{Buku}

[22] Andrey, S. (2016), Hukum HAM dan Hukum Humaniter, Jakarta: Rajagrafindo Persada.

[23]El-Muhtaj, M. (2013). Dimensi-Dimensi HAM: Mengurai Hak Ekonomi, Sosial, dan Budaya. Jakarta: Rajawali Press.

[24]Howard, R. E. (2000). HAM Penjelajahan Dalih Relativisme Budaya. (Terjemahan.), Kajatasungkana, Nugraha. Jakarta: Pustaka Utama Grafitri.

[25] Nowak, M. (2003). Introduction to The International Human Rights Regime. Brill Nijhoff.

[26] Riyadi, E. (2019). Hukum Hak Asasi Manusia Perspektif Internasional, Regional dan Nasional, Depok: Rajawali Pers.

[27] Samijo. (1996). Ilmu Negara. Bandung, Armico.

[28] Soekanto, S. (2006). Pengantar Penelitian Hukum. Jakarta: UI-Press.

[29] Steni, B. (2009). Politik Pengakuan Masyarakat Adat Atas Tanah Dan Sumber Daya Alam: dari Hindia Belanda hingga Indonesia Merdeka” dalam Sulistyowati Irianto (Ed), Hukum Yang Bergerak Tinjauan Antropologi Hukum. Jakarta: Yayasan Obor Indonesia.

[30] Suseno, F. M. (2001). Etika Politik: Prinsip-Prinsip Moral Dasar Kenegaraan Modern, Jakarta: Gramedia Pustaka Utama.

[31] Wattimena, J.A.Y. (2013). Prinsip-Prinsip Penanaman Modal Asing Dan Implementasinya Pada Masyarakat Hukum Adat. In Kumpulan Tulisan Dosen-Dosen Fakultas Hukum Universitas Pattimura. Ambon: Anugrah Sejati.

\section{Online/World Wide Web}

[32]Bina Desa. (2016). Kewajiban Negara dalam Hak Atas Pangan. https://binadesa.org/kewajiban-negara-dalam-hak-atas-pangan/.

[33] https://republika.co.id/berita/qg0ymn383/pandemi-covid19-ancam-ketahanan-panganglobal.

[34] https://infeksiemerging.kemkes.go.id/situasi-infeksi-emerging/situasi-terkiniperkembangan-coronavirus-disease-covid-19-27-juli-2020.

[35] https://infeksiemerging.kemkes.go.id/situasi-infeksi-emerging/situasi-terkiniperkembangan-coronavirus-disease-covid-19-26-desember-2020.

[36] http://www.aman.or.id/2020/05/aman-perkebunan-skala-besar-perparah-krisis-pangan-ditengah-covid-19/.

[37] https://www.komnasham.go.id/index.php/news/2018/4/19/519/tujuh-rekomendasi- 
pelapor-khusus-hak-atas-pangan.html.

[38] http://www.aman.or.id/2020/06/pernyataan-sikap-aman-kalimantan-tengah-terkaitrencana-food-estate-cetak-sawah/BENGKULU.

[39] https://nasional.kompas.com/read/2019/12/10/09145461/nasib-masyarakat-adat-yangterancam-investasi-hingga-kriminalisasi?page $=$ all.

[40] Mh Firdaus, http://asppuk.or.id/2020/06/07/pangan-lokal-di-tengah-pendemi-covid-19/. 